Int. J. Dev. Biol. 51: 597-608 (2007)

doi: $10.1387 / \mathrm{ijdb} .072392 \mathrm{gn}$

\title{
Development of the hair bundle and mechanotransduction
}

\author{
GOWRI D. NAYAK, HELEN S.K. RATNAYAKA, RICHARD J. GOODYEAR and GUY P. RICHARDSON* \\ School of Life Sciences, University of Sussex, Falmer, Brighton, BN1 9QG, U.K.
}

\begin{abstract}
This review focuses on the cellular and molecular mechanisms underlying the development of the sensory hair bundle, an apical specialisation of the hair cell that is essential for mechanotransduction. The structure, function and development of the hair bundle is described, with an emphasis on the properties and possible roles played by the different link types that interconnect the individual elements of the hair bundle - the multiple stereocilia and the single kinocilium. Studies of mouse and zebrafish mutants have revealed that several classes of molecule are required for the genesis and maintenance of hair-bundle structure. These include cell surface molecules that are associated with the different hair-bundle links, along with myosin motors, scaffolding proteins and an actin cross-linker. Finally we consider how differences in the form and shape of hair bundles within and between different sensory organs are generated.
\end{abstract}

KEY WORDS: inner ear, hair bundle, stereocilia, development

\section{Introduction}

The hair cells of vertebrates are polarised epithelial cells that are characterised by the presence of a mechanosensory hair bundle located at their apical pole. It is this intricate and delicate structure that gives hair cells their name and allows them to transduce mechanical stimuli into electrical signals. In this review we will focus on the molecular mechanisms underlying the genesis of this sensory organelle. How the hair bundles acquire their orientation within each sensory organ is the subject of another paper in this series (Chen et al., this volume).

\section{Structure and function of the hair bundle}

The hair bundle is composed of two or more rows of modified microvilli that are known as stereocilia. In all but the mature auditory organs of the inner ear, the hair bundle also contains a single true cilium, the kinocilium. The stereocilia are arranged in rows of increasing height with the kinocilium located adjacent to and central with respect to, the tallest row. The kinocilium has microtubule doublets extending throughout its length and a centriole lies at its base within the apical cytoplasm of the hair cell. The stereocilia are filled from top to bottom with numerous, highly cross-linked F-actin filaments. A proportion of these F-actin filaments pass through the tapered base of each stereocilium and form a rootlet that extends into the cuticular plate, a dense meshwork of actin and other cytoskeletal proteins that lies in the cell cytoplasm beneath each hair bundle. The F-actin filaments in the stereocilia are polarised with their plus (barbed) end located at the tip of each stereocilium. Recent evidence indicates the cytoskeletal core of the stereocilium is far from being a static, stable structure (Schneider et al., 2002; Rzadzinska et al., 2004) and the precise regulation of actin filament assembly is likely to be important for both the development and maintenance of hairbundle structure.

The elements of the hair bundle are interconnected by a number of different link types. The distribution of links within the hair bundle and the types of link present can vary according to hair-cell type and position within a given sensory organ and according to species, much in the same way that the overall shape and form of the hair bundle can vary from one organ to another and within the same organ. These various link types will be considered in some detail, as there is increasing evidence they play key roles in both the development and function of the hair bundle.

\section{Hair-bundle links}

Up to four morphologically and biochemically distinct link types can be distinguished running between the membranes of adjacent stereocilia in some types of hair bundle (see Fig. 1, Table 1).

Abbreviations used in this paper: ALA (ankle link antigen); BAPTA (1,2-bis[aminophenoxy] ethane-N, N, N', N'-tetra-acetic acid); IHC (inner hair cell); OHC (outer hair cell); PBM (PDZ-domain binding motif); PDZ domain (postsynaptic density, discs-large and zona-occludens); SEM (scanning electron microscopy); TEM (transmission electron microscopy); TLA (tip link antigen). 
Working from the top to the bottom of the hair bundle one can find tip links, horizontal top connectors, shaft connectors and ankle links. If a kinocilium is present, abundant kinocilial links (Hillman, 1969; Ernston and Smith, 1986; Bagger-Sjöbäck and Wersäll, 1973, Goodyear and Richardson, 2003) are also present and attach it to the immediately adjacent stereocilia in the tallest row. In mature hair cells and from all stereocilia except those in the tallest row, a single, obliquely-inclined tip link extends from the tip to the side of an adjacent taller stereocilium (Pickles et al., 1984; Furness and Hackney, 1985). The tip link appears to be a single strand formed from two helically intertwined filaments along most of its length, although it may branch into two or more anchoring filaments at either end (Kachar et al., 2000; Tsuprun et al., 2004). Tip links connect the stereocilia of adjacent, height-ranked rows. In contrast to these obliquely oriented tip links, there are multiple copies of the other link types between each stereocilium and they tend to run parallel to the hair cell's apical surface, interconnecting adjacent stereocilia both within and across the rows. Horizontal top connectors are found just below the tips of the stereocilia. In birds, fishes and frogs these connectors bear a resemblance to invertebrate septate junctions and are formed from arrays or plaques of short, regularly packed, dense-staining bars that span the gap between adjacent membranes (Neugebauer and Thurm, 1985; Nagel et al., 1991; Goodyear and Richardson, 1992). Top connectors of this description are not found in all types of hair bundle in the bird's inner ear and are restricted to those in the striolar regions of the maculae, the central regions of the cristae and the auditory organ (Goodyear and Richardson, 1992). In mammalian outer hair cells (OHCs), top connectors are of a different morphological appearance (Furness and Hackney, 1985; Tsuprun and Santi, 1998; 2002; Tsuprun et al., 2003; Goodyear et al., 2005) and have a distinct central density where the filaments from adjacent membranes appear to interconnect. The top connectors of mammalian inner hair cells (IHCs) appear to be less well developed than those of OHCs and seem to lack the central density (Slepecky and Chamberlain, 1985; Prieto and Merchan, 1986; Santi and Anderson, 1987; Tsuprun et al., 2003).

In the bird ear, hair bundles that have horizontal top connectors have shaft connectors restricted to the basal third or so of each stereocilium, whereas those that lack top connectors have shaft connectors distributed fairly evenly over the entire hair-bundle surface (Goodyear and Richardson, 1992). In specimens that have been prepared in the presence of ruthenium red, shaft connectors are formed from an electron-dense spherical element that is suspended between the membranes of adjacent stereocilia

TABLE 1

CHARACTERISTICS OF HAIR-BUNDLE LINKS

\begin{tabular}{lccccc} 
& $\begin{array}{c}\text { Kinocilial } \\
\text { links }\end{array}$ & $\begin{array}{c}\text { Tip } \\
\text { links }\end{array}$ & $\begin{array}{c}\text { Top } \\
\text { connectors }\end{array}$ & $\begin{array}{c}\text { Shaft } \\
\text { connectors }\end{array}$ & $\begin{array}{c}\text { Ankle } \\
\text { links }\end{array}$ \\
\hline BAPTA & + & + & - & - & + \\
Subtilisin & - & - & - & + & + \\
Associated antigens & $\begin{array}{c}\text { Cdh23 } \\
\text { Pcdh15 (TLA) }\end{array}$ & $\begin{array}{c}\text { Cdh23 } \\
\text { Pcdh15(TLA) }\end{array}$ & $?$ & Ptprq & $\begin{array}{r}\text { Vlgr1 (ALA) } \\
\text { Usherin }\end{array}$ \\
\hline
\end{tabular}

Table summarising the sensitivity of the different hair-bundle link types to the calcium chelators, BAPTA and the protease subtilisin. A plus $(+)$ sign indicates sensitivity, a negative $(-)$ sign indicates resistance. Associated antigens are also indicated. Cdh23, cadherin 23; Pcdh15, protocadherin 15; TLA, tip link antigen (avian Pcdh15); ALA, ankle link antigen (avian Vlgr1); usherin (long isoform of usherin). by numerous fine filaments (Goodyear and Richardson, 1992).

Ankle links are apparently single-stranded, long thin filaments that form a dense web-like mesh that is confined to a narrow zone lying just above the region where the stereocilia taper before they insert into the hair cell's apical surface (Neugebauer and Thurm, 1985; Csukas etal., 1987; Jacobs and Hudspeth, 1990; Goodyear and Richardson, 1992) Although present on all mature hair-cell types in the bird ear, they are, for example, only a transient feature of developing mammalian hair cells (Goodyear et al., 2005).

\section{Functions and properties of hair-bundle links}

Tip links are generally thought to be linked to and gate the hair cell's mechanotransducer channel (Fettiplace, 2006). They are uniquely oriented along the hair bundle's axis of mechanosensitivity, run parallel to the hair bundle's axis of bilateral symmetry and their oblique disposition indicates they will be stretched or apply tension to an attached channel only when the hair bundle is displaced in the excitatory direction, i.e., towards the kinocilium or the tallest row of stereocilia. Tips links are sensitive to calcium chelation with BAPTA (Assad et al., 1991; Goodyear and Richardson, 1999), an agent that disrupts transduction (Assad et al., 1991, Michel et al., 2005) and resist treatment with the protease subtilisin (Jacobs and Hudspeth, 1990, Goodyear and Richardson, 1999), a procedure that does not appear to influence the amplitude of transduction currents (Michel et al., 2005). Kinocilial links have similar properties to tip links and are also BAPTA-sensitive, subtilisin-resistant structures (Goodyear and Richardson, 2003).

The orientation and properties of the other link types, collectively referred to as lateral links, suggests they are unlikely to be involved in the mechanotransduction process. They are aligned along three of the lattice planes of the hex-packed hair bundle and their relative sensitivities to BAPTA and subtilisin (see Table 1) are not consistent with a role in gating the transducer channel. Top connectors are resistant to both BAPTA and subtilisin, shaft connectors are BAPTA-insensitive, subtilisin-sensitive and ankle links are degraded by treatment with either agent (Goodyear and Richardson, 1999). Lateral links are generally considered to play a role in transmitting forces across the hair bundle and/or in maintaining the integrity of the structure.

\section{How the hair bundle develops}

The morphological details of hair-bundle development have been most extensively studied in the avian auditory organ, the basilar papilla (Tilney et al., 1992 for review). In brief, three phases can be described. During the first phase, numerous short microvilli appear on the apical surface surrounding a single centrally located kinocilium. These microvilli are only just distinguishable from those on the surrounding supporting cells and contain only a few, peripherally located F-actin filaments. The kinocilium then migrates to the periphery of the cell surface and short microvilli that are nearest to it begin to elongate, followed successively by those in rows that are further and further away. The sequential initiation of stereociliary elongation in rows located more distal to the kinocilium is the process that initially generates rows of height-ranked stereocilia. During this brief initial period, which lasts from 2-3 days and begins simultaneously throughout 


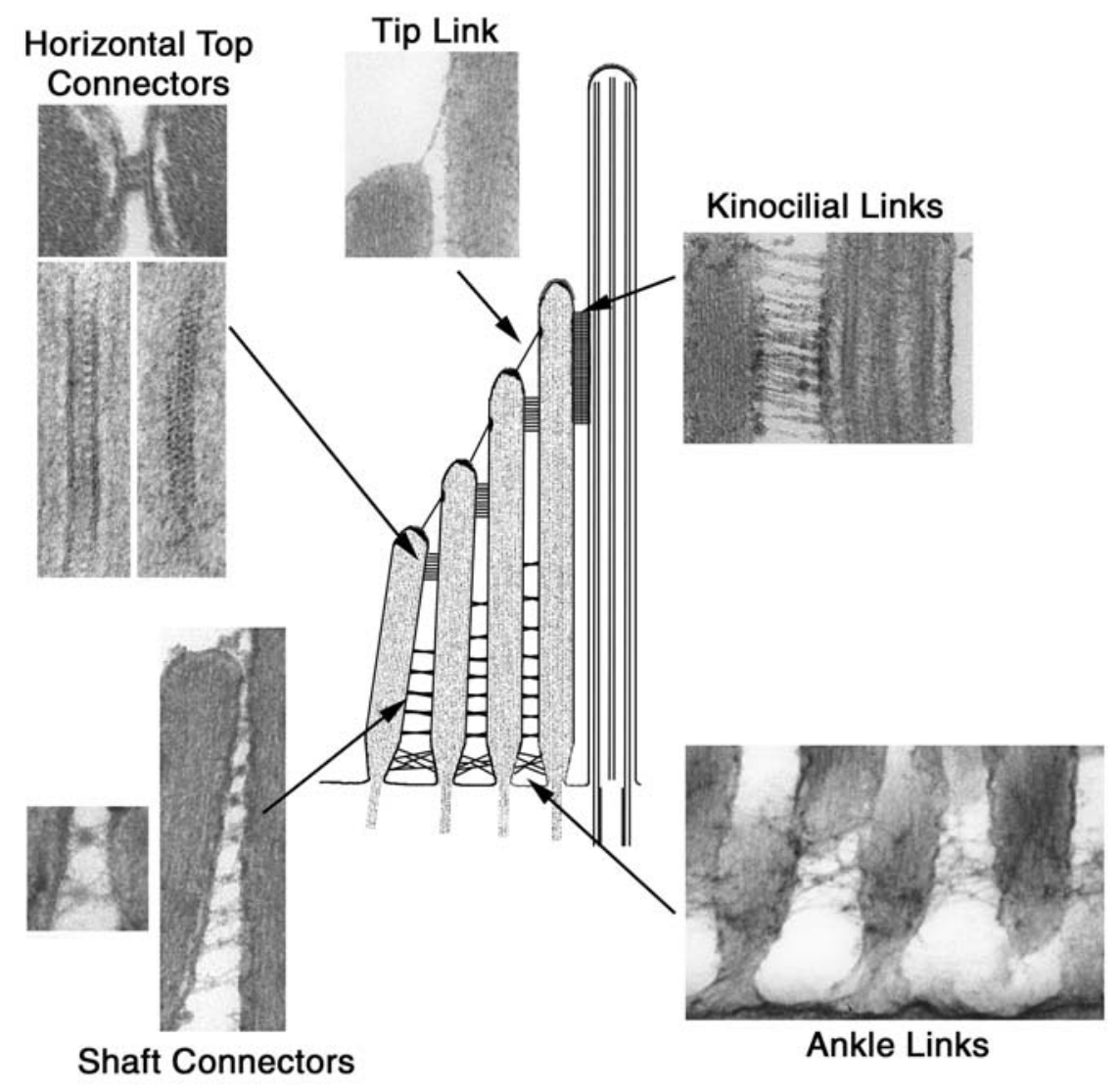

Fig. 1. Hair bundle links. Diagram (centre) illustrating the five link types associated with hair bundles in the inner ear; tip links, kinocilial links, horizontal top connectors, shaft connectors and ankle links. Surrounding electron micrographs illustrate the ultrastructural appearance of each link type. For the horizontal top connectors, section planes are parallel (top image) and orthogonal (lower two images) to the hair cell's apical surface, with the lower right image being a grazing en face section of a stereocilium. All other images are from sections cut orthogonal to the hair cell's apical surface. Images are adapted from Goodyear and Richardson, 1992; 2003 and Goodyear et al., 2003 with permission from the publishers (John Wiley and Sons, Inc. and Society for Neuroscience).

the length of the organ, the number of actin filaments within each stereocilium increases and the filaments appear to become more cross-linked. In the next phase, which can last up to 5 days, the stereocilia do not become any longer but they increase in width and elaborate rootlets that project down into the cuticular plate that is developing beneath the hair bundle. During the third and final phase of hair bundle development in this auditory organ, those hair bundles that have not reached their final desired height begin to elongate. At the onset of this phase, the stereocilia in all the rows begin to elongate simultaneously, but at the end of this phase those in the shortest row stop first and those in the tallest row stop last, thereby exaggerating the difference in height ranking between the rows. Thus it is the sequential initiation and termination of stereociliary elongation, with those in the tallest row starting first and finishing last and those in the shortest row starting last and finishing first, that generates the familiar and essential 'staircase' arrangement of stereociliary rows in the hair bundle. Differences in overall hair bundle height that occur along the length of the organ, with those in the proximal high-frequency end being shorter than those in the distal low-frequency end, are generated by extending the period of growth, with the taller ones in the distal parts of the papilla growing for longer than the shorter ones at the proximal end.

A broadly similar process has been described for hair-bundle development in the vestibular and cochlear systems of mammals (Mbiene and Sans, 1986; Zine and Romand, 1996; Denman-Johnson and Forge, 1999). Things may, however, happen much faster in the mammalian vestibule (Denman-Johnson and Forge, 1999) and, in the hamster cochlea (Kaltenbach et al., 1994), there is no evidence for the elongation and thickening of stereocilia being separated into temporally distinct phases. Both may happen simultaneously and differences in hairbundle height along the length of the organ may be a result of different growth rates, rather than due to differences in the time period over which stereocilia elongate at a constant rate as proposed for the bird hearing organ.

\section{Development of links}

The development of hair-bundle links has been studied in detail for the hair cells of the avian basilar papilla and in the OHCs of the mouse cochlea (Pickles et al., 1991; Goodyear et al., 2005). Abundant links are associated with the surface of immature developing hair bundles and on the basis of morphological studies alone it is not clear to which class or type these multiple links belong. In the bird papilla, SEM studies originally suggested tip and ankle links both develop from the spokelike, radial arrays of multiple links that are found interconnecting the distal tips of the short immature stereocilia prior to their elongation (Pickles et al., 1991). Immunohistochemical studies with monoclonal antibodies indicate that proteins associated with ankle links, tip links and shaft connectors are distributed all over the surface of the developing stereocilia of immature hair bundles in the avian papilla before becoming restricted to their normal, adult-type distributions (Bartolami et al., 1991; Goodyear and Richardson, 1999; 2003). In mammalian OHCs, cadherin23, thought to be a component of tip and kinocilial links (Sollner et al., 2004; Siemens et al., 2004), is initially distributed widely over the surface of the developing stereocilia in association with the transient lateral links (Michel et al., 2005), becoming progressively located towards the top of the stereocilia in the cochlea as development proceeds. Ankle links become morphologically distinct entities on developing mouse cochlear OHCs just after birth, at around $\mathrm{P} 1$, and are only a transient feature, disappearing by $\mathrm{P} 11$ concomitant with the loss in immunoreactivity for Vlgr1 and usherin (Goodyear et al., 2005; McGee et al., 2006, Adato et al., 2005a). Ptprq, a shaft connector component, is also only transiently expressed on mouse cochlear $\mathrm{OHC}$ stereocilia, for a period of about two weeks between embryonic day 17 and postnatal day 15 , but continues to be expressed in the hair 
bundles of IHCs and those of the vestibular organs throughout life (Goodyear et al., 2003). The disappearance of ankle links and Ptprq from the hair bundles of mouse cochlear OHCs is coincident with the appearance of the well defined horizontal top connectors characteristic for this cell type (Goodyear et al., 2005), suggesting these junction-like connectors may play a key role in maintaining integrity of the hair bundle of the mature $\mathrm{OHC}$.

\section{Development of transduction}

Due to the presence of multiple links on developing hair bundles, it is not clear when definitive tip links first appear in developing hair cells. In the bird, transducer currents and loading with the styryl dye FM1-43, a permeant blocker of the hair cell's mechanotransducer channel (Gale et al., 2001), can be first measured and detected at embryonic day 12 (Si et al., 2003). This is some three days after oblique links can be first seen extending from the stereociliary tips by SEM (at E9, coincident with the onset of phase 1 elongation) and shortly before the densities that characterise the insertion points (attachment plaques) of the tip links can be first sporadically observed by TEM (at E13) (Pickles et al., 1991). In the mouse utricle, measures of transduction currents and FM1-43 dye loading indicate transduction begins at E17 (Géléoc and Holt, 2003), some 2 days after the first appearance of potential tip links (Denman-Johnson and Forge, 1999). Potential tip links have been observed by SEM in the rat IHCs at birth (Zine and Romand, 1996), in gerbil OHCs by P2 (Souter et al., 1995) and in cultured mouse OHCs at the equivalent of P3 (Furness et al., 1989). Oblique links can be seen at stereociliary tips in mouse cochlear basal coil OHCs at E17.5 (Goodyear et al., 2005), shortly before the onset of FM1-43 dye loading and the detection of transduction currents in response to hair-bundle deflections (at PO in basal-coil OHCs, Marcotti, Richardson and Kros, unpublished observations).

In the developing bird cochlea (Si et al., 2003), the transduction currents measured at the onset of transduction have a broad operating range, are small in amplitude, show little sign of adaptation and the open probability at rest is high ( 0.5). Adult-like characteristics are acquired over a period of 5-10 days. In contrast, the mature adult-like properties of the transduction apparatus within the developing mouse utricle are acquired within 24 hours of the onset of transduction (Géléoc and Holt, 2003).

\section{Molecular basis of hair-bundle development}

Considerable insight into the mechanisms that may underlie the development and maintenance of hair-bundle structure has been recently provided by the study of mouse and zebrafish mutants and the discovery of genes required for hearing, the socalled 'deafness' genes. These studies have revealed critical roles for cell surface proteins associated with some of the various link types, along with roles for different myosin motors, scaffolding proteins and actin cross linkers.

\section{Cell surface proteins}

\section{Cadherin23 and protocadherin15}

Five different cell surface molecules have been associated with the various hair-bundle link types (see Table 1). Cadherin23
(Cdh23) with tip links, kinocilial links and transient lateral links (Sollner et al., 2004; Siemens et al., 2004; Michel et al., 2005), protocadherin15 (Pcdh15) with tip and kinocilial links (Ahmed et al., 2006), and protein tyrosine phosphatase receptor $Q$ (Ptprq) with shaft connectors (Goodyear et al., 2003). The very large Gprotein coupled receptor 1 (VIgr1) and usherin are associated with ankle links (McGee et al., 2006, Adato et al., 2005a). In mice, Cdh23, Pcdh15, Ptprq and Vlgr1 are all known to be required for the development and maintenance of hair-bundle structure (DiPalma et al., 2001a; Wilson et al., 2001; Alagramam et al., 2001; Goodyear et al., 2003; McGee et al., 2006; Yagi et al., 2007).

Cdh23 and Pcdh15 are members of the cadherin superfamily of cell-cell adhesion molecules, transmembrane proteins that play crucial roles during embryogenesis and organogenesis. Classical cadherins interact through the formation of anti-parallel dimers and are known to mediate basic cellular processes like cell-cell adhesion, cell sorting and migration (Tepass et al., 2000). The cadherin extracellular domain possesses a variable number of repeat sequences or cadherin motifs that are required for cellcell adhesion. Calcium is required for stabilising these extracellular cadherin domains and for the subsequent adhesion of adjacent cells. The cadherin cytoplasmic domain interacts with cytoskeletal and other intracellular signalling proteins (Goodwin and Yap, 2004). Cdh23 and Pchd15 both differ from classical cadherins. They possess numerous extracellular cadherin repeats (EC domains) in their ectodomains (El-Amraoui and Petit, 2005), lack the consensus R1 and R2 binding sites for $\beta$-catenins (Imamura et al., 1999) in their intracellular domains and possess class I PDZ-binding motifs (PBMs) at the C-terminus of their cytoplasmic tail (Ahmed et al., 2001; Boëda et al., 2002; Bork et al., 2001; Siemens et al., 2002).

Cdh23 is characterized by an extremely long extracellular domain with $27 \mathrm{EC}$ domains, a transmembrane region and a short cytoplasmic domain with no similarity to any known proteins (Di Palma et al., 2001b). Three isoforms of Cdh23 are expressed in the mouse inner ear, isoforms A, B and C (Di Palma et al., 2001b; Bork et al., 2001; Michel et al., 2005; Siemens et al., 2002). The $A$ isoform contains $27 \mathrm{EC}$ domains, the $B$ isoform has $7 \mathrm{EC}$ domains and the $\mathrm{C}$ isoform comprises only the cytoplasmic domain (Lagziel et al., 2005). Additional splice variants differ in their intracellular regions owing to either the presence or absence of sequence encoded by exon 68, a 35 amino acid insert found in the cytoplasmic domain (Siemens et al., 2002, Lagziel et al., 2005; Michel et al., 2005). The $C$ isoform, if expressed as a stable protein, may compete with the other Cdh23 isoforms for cytoplasmic binding partners (Michel et al., 2005; Lagziel et al., 2005). Immunofluorescence studies with antibodies directed against either the intra or extracellular domains indicate Cdh23 is expressed at high levels during the early stages of hair-bundle development and associated with both transient lateral links and kinocilial links (Boëda et al., 2002; Michel et al., 2005; Siemens et al., 2004). As the hair bundle develops, Cdh23 becomes progressively restricted to the tips of the stereocilia (Michel et al., 2005; Lagziel et al., 2005), where it may remain associated with the tip links (Siemens et al., 2004).

Pcdh15 has $11 \mathrm{EC}$ domains, a single transmembrane domain and a cytoplasmic domain terminating with a class I, C-terminal, PBM (Demontis et al., 2006). RT-PCR experiments indicate 
mRNAs encoding up to 24 different isoforms of Pcdh15 may be expressed in the developing mouse inner ear (Ahmed et al., 2006). These fall into four isoform classes, three of which, CD1, CD2 and CD3, have distinct intracellular domains. The fourth class lacks a transmembrane domain and is likely to be a secreted isoform. Antibodies specific for the three transmembrane forms of Pcdh15 indicate the CD1 isoform is expressed in a uniform manner on the surface of the developing hair bundle but excluded from the very tip of mature stereocilia, that CD2 is expressed in the kinocilium and in developing but not mature stereocilia and that CD3 is expressed at the tips of the stereocilia (Ahmed et al., 2006). The distributions of CD1 and CD3 are such that they could be associated with the top and bottom end of the tip link, respectively.

The phenotypes of mice with mutations in either Cdh23 (Waltzer mice, v) or Pcdh15 (Ames waltzer, av) are consistent with these proteins playing a role in maintaining the cohesion of the hairbundle elements (DiPalma et al., 2001a; Alagramam etal., 2001). Disorganisation and fragmentation of the hair bundle into several clumps of stereocilia, along with a misplaced kinocilium, are common features of hair bundles in these mutants (Fig. 2A, B). It should, however, be noted that there are height ranked rows of stereocilia within the individual clumps and that the stereocilia within the individual clumps appear to be held together, indicating there is likely to be some degree of redundancy in the interstereociliary adhesion process. Splayed hair bundles are also a feature of the zebrafish sputnikand orbiter mutants (Nicolson et al., 1998) that have mutations in Cdh23 and Pcdh15 respectively (Ernest et al., 2000; Seiler et al., 2005).

\section{Ptprq}

Ptprq is a receptor-like inositol lipid phosphatase (Oganesian et al., 2003). It was originally identified as the hair-cell antigen (HCA) in a monoclonal antibody screen for hair-bundle specific proteins (Richardson et al., 1990; Goodyear et al., 2003). Ptprq has an ectodomain containing 18 fibronectin type III (FN3) repeats, a single pass transmembrane region and an intracellular domain that has activity against a broad spectrum of inositol phospholipid substrates (Oganesian et al., 2003). In the mouse, alternative splicing and use of an alternative promoter generates three Ptprq isoforms; a full-length form, a membrane-tethered ectodomain lacking an intracellular catalytic domain and a nonmembrane-tethered cytoplasmic form (Seifert et al., 2003).

Although expressed from the earliest stages of hair-bundle development onwards in the developing avian inner ear (Bartolami etal., 1991), Ptprq is first detected on the stereocilia of mouse hair bundles 1-3 days after the bundles have first emerged (Goodyear et al., 2003). In basal-coil OHCs of the mouse inner ear, Ptprq is only expressed transiently during a period of about 2 weeks, from E18.5 through to P15, although it is expressed into maturity in the hair bundles of all other types of mouse hair cell.

In transgenic mice lacking Ptprq, varying degrees of hairbundle disorganization and bundle shortening can be observed in the basal regions of the cochlea by P1 (Goodyear et al., 2003). By P8, many stereocilia on IHCs are missing, misaligned or fused together. Stereocilia of $\mathrm{OHCs}$ are also either lost or misaligned but rarely fused together. When present, the hair bundles of OHCs are shorter than in wild type littermates and are more U-shaped (Fig. 2F). The hair cells otherwise appear normal until at least
P22, after which the organ of Corti degenerates. In contrast, the vestibular hair cells of Ptprq mutants are relatively unaffected; they survive into adulthood and the mice do not exhibit any overt vestibular phenotype although the hair bundles are, at postnatal stages of development, shorter than those in heterozygous littermate controls (Goodyear and Richardson, unpublished observations). Despite the loss of shaft connectors in the vestibular hair bundles of Ptprq mutants, the stereocilia show no signs of splaying, suggesting this link type is not required for cohesion of the stereocilia. Ptprq is, however, required for the complete maturation and maintenance of cochlear hair bundles (Goodyear etal., 2003). Inositol phospholipids are known to be key regulators of the actin cytoskeleton (Takenawa and Itoh, 2001) and Ptprq may regulate the local inositol phospholipid content and consequently regulate the rate of membrane and actin turnover at the apical end of the hair cell (Goodyear et al., 2003). Functional redundancy may compensate for the loss of Ptprq and explain the apparent difference in susceptibility seen in the different hair cell types.

\section{Vlgr1}

Vlgr1 is a member of the secretin family (family 2 or B) of Gprotein-coupled receptors and is one of the largest cell membrane proteins known (McMillan et al., 2002). It comprises a very large ectodomain consisting of 34 calcium-binding Calx- $\beta$ repeats, one LamG/TspN/PTX domain and a set of EAR/EPTP repeats, and has a predicted 7-pass transmembrane domain characteristic of G-protein coupled receptors. Vlgr1 has recently been identified as the ankle link antigen (ALA, Goodyear and Richardson, 1999; McGee et al., 2006). Although the ALA is expressed throughout the lifetime of chick hair bundles, VIgr1 is only expressed until P11 on hair bundles in the mouse inner ear. The normal developmental loss of Vlgr1 from mouse hair cells correlates with the disappearance of ankle links from the hair bundles and ankle links are completely absent in the cochleae of mice in which the 7 transmembrane domain of VIgr1 has been deleted (McGee et al., 2006). The hair bundles in the cochlea of VIgr1 mutants go through the early stages of development, but suddenly lose their characteristic tight Vshape and become poorly aligned shortly after the time at which ankle links would normally become morphologically discernable (Johnson et al., 2005; McGee et al., 2006). VIgr1 appears to be involved in the later stages of hair-bundle genesis and is clearly required during a brief, critical period in the early postnatal development of cochlear hair cells. In contrast, the hair cell bundles of vestibular hair cells do not display such an absolute requirement for VIgr1 for their development and survival (McGee et al., 2006).

\section{Usherin}

Mutations in the gene encoding usherin underlie USH2A, the most common genetic form of the deaf/blindness Usher syndrome (Eudy et al., 1998; Van Wijk et al., 2004). The USH2A gene codes for two isoforms, a short and a long isoform (Eudy et al., 1998; Van Wijk et al., 2004). The short isoform, isoform a, consists of an $\mathrm{N}$-terminal signal peptide followed by one laminin G-like domain (LamGL), one laminin N-terminal domain (LamNT), 10 laminin-type EGF-like modules and two sets of FN3 repeats spaced by two laminin G (LamG) domains. The 
longer isoform, isoform b, contains, in addition to the previously described functional domains, two LamG domains, 28 FN3 repeats, a transmembrane region and a cytoplasmic domain with a class I PBM at its C-terminal end (Eudy et al., 1998; Van Wijk et al., 2004). In cochlear hair cells, usherin is localized in the stereocilia and at the synaptic region (Reiners et al., 2005; Liu et al., 2007) and has recently been suggested to be a component of the ankle links (Adato et al., 2005a). The spatiotemporal pattern of expression of usherin in the mouse inner ear is similar to that reported for ankle links. At E18 usherin is detected along the entire surface of $\mathrm{OHC}$ stereocilia and at E20 is restricted to the base of the stereocilia of both inner and OHCs. Usherin then starts to fade out and disappear from the cochlear hair cells by P10, although it persists in the mature vestibular hair cells (Adato et al., 2005a). The phenotype of usherin null mutant mice has yet to be described.

\section{Myosin motors}

Myosins are molecular motors that use actin filaments as a substrate, generating force and movement in response to the hydrolysis of ATP (Henn \& De La Cruz, 2005; Mooseker \& Cheney, 1995). All myosins have a conserved head region with sites for binding actin and ATP, a neck region composed of one or more isoleucine and glutamine rich regions (IQ domains) and a C-terminal, class-specific tail region with a number of different motifs. Mutations in three unconventional myosins, myosin $\mathrm{VI}$, myosin VIla and myosin XVa are known to cause defects in hair-bundle development (Avraham et al., 1995; Gibson et al., 1995; Anderson et al., 2000). Myosin VI is unusual in as much as it is the only known myosin motor that moves towards the pointed, or minus, end of actin filaments (Wells et al., 1999). All other myosins move toward the barbed, or plus, end of actin filaments, the preferred end for actin monomer addition.

Myosin VI is present at high levels in the cytoplasm and cuticular plate of hair cells and is also present in the stereocilia (although levels in the hair bundle may vary according to species) and can be detected in hair cells soon after their birth (Hasson et al., 1997). In the Snell's waltzer mouse with an effective null mutation in myosin VI, hair-bundle defects are apparent at birth and include malfor-

C

D
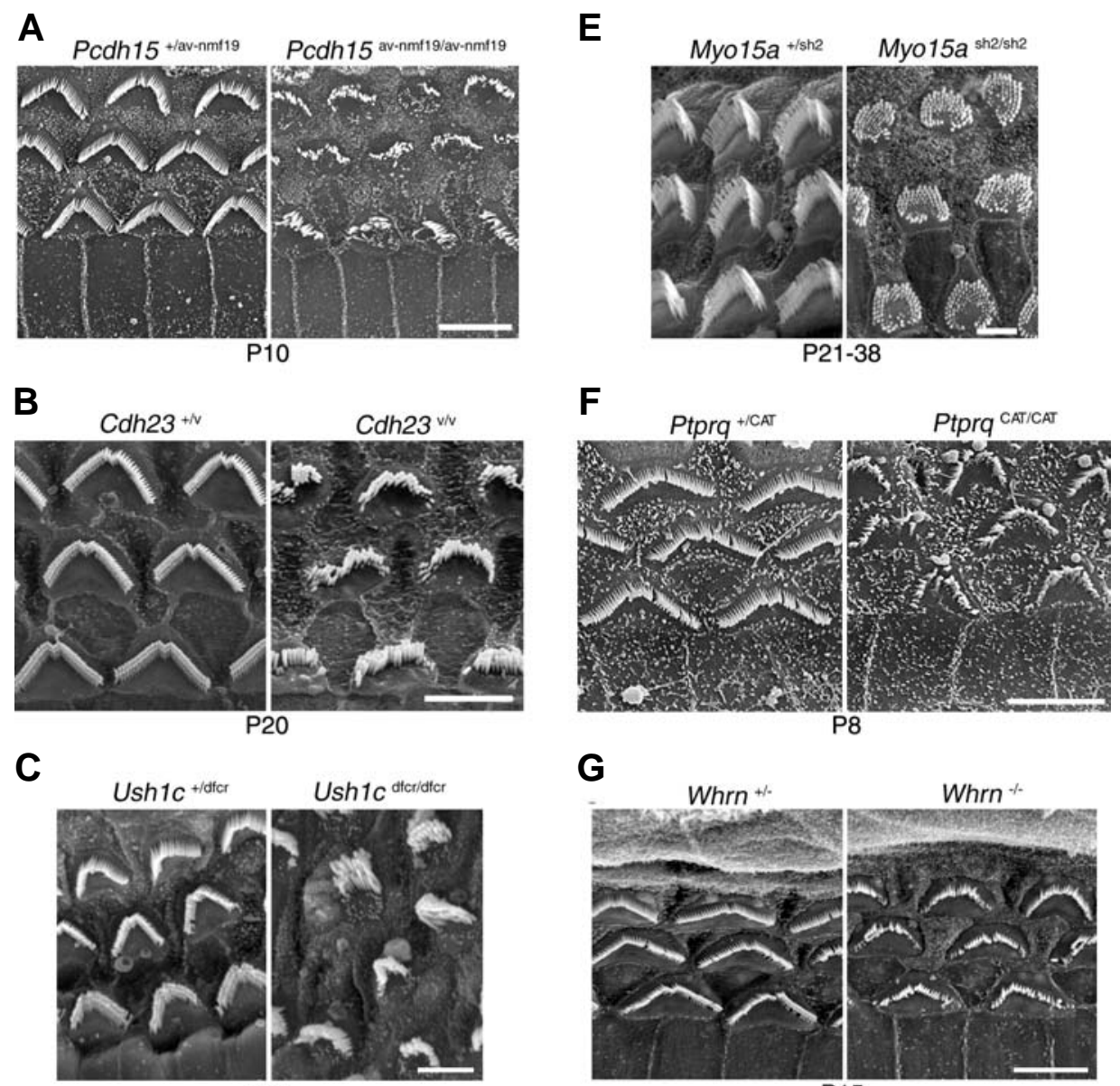

P21

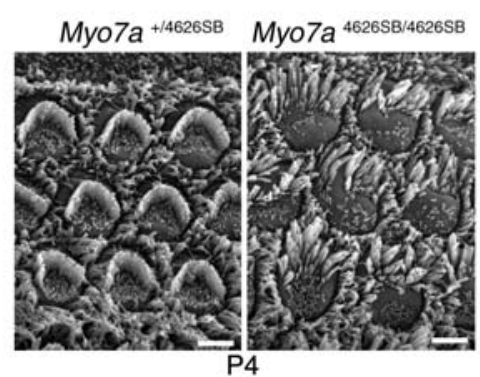

G

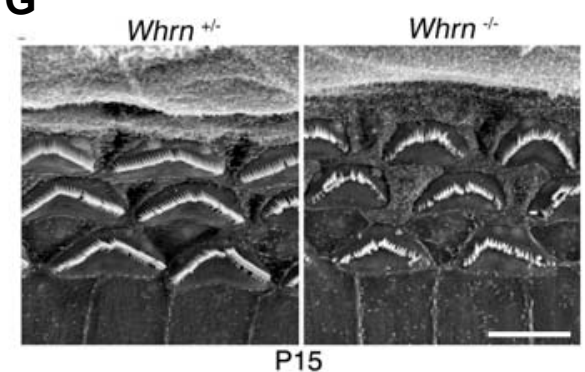

H

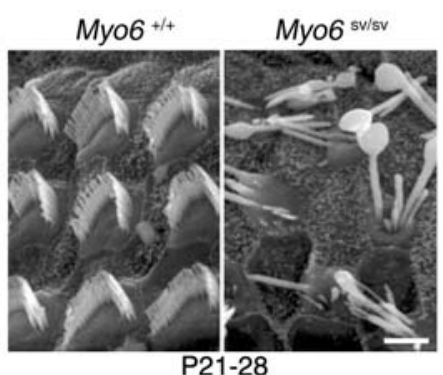

Fig. 2. Hair bundle morphology in mutant mouse strains. Scanning electron micrographs showing the hair bundles of cochlear outer hair cells from mice with mutations in (A) protocadherin 15, (B) cadherin 23, (C) harmonin (D) myosin 7a, (E) myosin XVa, (F) Ptprq, (G) whirlin and (H) myosin VI. In each pair of micrographs the image on the left is from a heterozygous or a wild type control and that on the right is from the homozygous mutant. Mutations in orthologues of the Usher Type I syndrome genes generate splayed hair bundles (A-D), mutations in myosin XVa, whirlin and Ptprq have short hair bundles (E-G) and mutations in myosin VI cause hair bundle fusion (H). Images are adapted from Washington III et al., 2005 (A), Holme and Steel, 2002 (B,D), Johnson et al., 2003 (C), Karolyi et al., 2003 (E,H), Mburu et al., 2003 (G) and Goodyear et al., 2003 (F) with permission from the authors and the publishers $(A, B, D$, Elsevier; $C E H$, Oxford University Press; F, Society for Neuroscience; G, Nature Publishing Group). Bars, $5 \mu \mathrm{m}$. mations in hair-bundle shape (Self et al., 1999). Giant fused stereocilia then become apparent (see Fig. $2 \mathrm{H}$ ) and it has been suggested that myosin VI may, as a minus end directed motor, tether the membrane around the base of each developing stereocilium to the actin-rich cuticular plate (Cramer, 2000). 
Myosin VI is known to play a pivotal role in apical endocytosis in polarised epithelial cells (Buss et al., 2001) and studies in the zebra-fish satellite mutant with mutations in myo6b have suggested it may maintain the integrity of the hair-cell's apical surface (Seiler at el., 2004).

Myosin VIla is widely distributed throughout the hair cell and may be concentrated in the ankle link region of the hair bundle in some species (Hasson et al., 1997). Shaker1 mice have mutations in the gene encoding myosin VIla (Gibson et al., 1995). In the more severe Shaker1 alleles, the effective nulls like sh6J and sh4626SB, severe hair-bundle disruption is seen by or shortly after birth and the hair bundles are often split into multiple small clumps that are randomly arranged on the cell surface (see Fig. 2D) (Self et al., 1998). A similar, splayed hairbundle phenotype is also seen in the zebrafish mutant, mariner (Ernest et al., 2000).

Myosin XVa is found in the hair-cell soma and concentrated at the tips of stereocilia where the amount present is proportional to the length of the stereocilium with the tallest stereocilia having the highest concentration (Anderson et al., 2000; Belyantseva et al., 2003; Rzadzinska et al., 2004). In shaker2 mice with recessive mutations in the MyoXVa gene, the protein is absent from the hair bundle and the stereocilia are abnormally short, although the rows of stereocilia still show evidence for being ranked in height (see Fig. 2E) (Anderson et al., 2000; Beyer et al., 2000). Hair bundles with height-ranked rows of stereocilia are also found in mice with mutations in either myosin VI or myosin VIIa, but mutations in each of the three myosins described above generate distinct hair-bundle phenotypes; fused in myosin VI mutants, fragmented and disorganised in myosin VIla mutants and short in myosin XVa mutants.

\section{PDZ-domain and PDZ-domain-binding proteins}

Proteins containing PDZ (for postsynaptic density, discslarge and zona-occludens) domains are generally thought to organise membrane associated multi-protein complexes (Zimmermann, 2006). Mutations in two PDZ-domain proteins, whirlin and harmonin, are known to affect hair-bundle development in mouse mutants (Holme et al., 2002, Mburu et al., 2003; Johnson et al., 2003), as do defects in a PDZ binding domain protein known as Sans (Weil et al., 2003; Kikkawa et al., 2003).

Two studies have indicated that whirlin is only expressed transiently in developing hair bundles, localising to both the tips and bases of the stereocilia (Kikkawa et al., 2005; Delprat et al., 2005). In the mouse, whirlin first appears at the tips of the stereocilia in the tallest row and appears last at the tips of those of the shortest rows (Kikkawa et al., 2005) and is apparently lost in the same order, first from the tallest and last from the shortest. Whirlin immunoreactivity has, however, been reported to be present at the tips of stereocilia in both the mature rat and mouse cochlea (Belyantseva et al., 2005; van Wijk et al., 2006). The progressive appearance of whirlin at the tips of stereocilia occurs during the early postnatal stages of hair bundle development after the initial development of height-ranked rows of stereocilia. In mice with a large deletion in the whirlin gene, the hair bundles are of normal orientation and have height-ranked rows of stereocilia, but are, like those of shaker2 mice with mutations in the myo15a gene, abnormally short (see Fig. 2G) (Holme et al., 2002). A long and a short isoform of whirlin are transcribed by alternative splicing, with the long form containing a proline-rich (PR) domain and three PDZ domains and the short C-terminal form containing only the PR and the third PDZ domain. The whirlin phenotype can be rescued by overexpressing the short form alone (Mburu et al., 2003). Whirlin interacts with the third PDZ domain of myosin $\mathrm{XVa}$, is absent from the tips of stereocilia in shaker2 mice and the overexpression of wild type myosin $\mathrm{XVa}$ in the hair cells of shaker2 mice recruits endogenous whirlin to the tips of stereocilia and restores hair-bundle elongation (Belyantseva et al., 2005). There is therefore good evidence that myosin XVa delivers whirlin to the stereociliary tips and that both proteins are required for the programmed elongation of stereocilia, although neither appear to be required for the initial stages of hair-bundle morphogenesis.

Recent evidence suggests the membrane-associated guanylate kinase (MAGUK) protein, p55 and protein 4.1R also interact with whirlin and may together form a complex responsible for mediating actin polymerisation and stereocilia development (Mburu et al., 2006). The PDZ1 domain of whirlin can also interact with the cytoplasmic tails of usherin and VIgr1, both of which contain a C-terminal class I PBM (van Wijk et al., 2006) and it has been suggested that whirlin may be involved in the anchoring of the ankle links through its associations with usherin and VIgr1 and also with myosin VIla (van Wijk et al., 2006; Adato et al., 2005b; Kremer et al., 2006).

There are multiple harmonin isoforms that can be classified into three discrete groups, $a, b$ and $c$, with the harmonin $b$ isoform being preferentially expressed in the inner ear (Verpy et al., 2000). Harmonin b has 3 PDZ domains, 2 coiled-coil domains that may allow dimerisation, a proline/serine/threonine rich region and itself contains a $\mathrm{C}$-terminal $\mathrm{PBM}$. In vitro harmonin $b$ has actin bundling activity, can interact with the tail of myosin VIla via its PDZ1 domain, and with both Cdh23 and Pcdh15 via its PDZ2 domain (Boëda et al., 2002; Adato et al., $2005 b)$. Harmonin b is expressed in the hair bundle as it first appears, and its location in this structure depends on the presence of myosin VIla (Boëda et al., 2002). The deaf circler and deaf circler 2 Jackson mice have mutations in the harmonin gene (Ush1c) that affect the expression of harmonin $a$ and $b$ and harmonin b, respectively (Johnson et al., 2003). Both mice have defects in hair-bundle development, showing signs of disorganisation and splaying of the stereocilia (see Fig. 2C) that are not entirely dissimilar to those seen in mice with mutations in either myosin VIla, Cdh23 or Pcdh15.

Sans is a scaffolding protein with three $\mathrm{N}$-terminal ankyrin repeats, a central region followed by a sterile alpha motif (SAM) domain and a class 1 PBM at the C-terminus (Nourry et al., 2003; Sedgwick and Smerdon, 1999). The ankyrin repeats, known to be involved in protein binding, do not appear to participate in the protein interactions exhibited by Sans (Adato et al., 2005b). Instead, Sans binds to the PDZ1 and PDZ2 of harmonin through its SAM domain while the central region of Sans mediates binding to domains in the tail of myoVIla (Adato et al., 2005b). In the developing inner ear, Sans is found localized in the apical region of the hair-cell soma, beneath the cuticular plate of cochlear and vestibular hair cells, but not in the stereocilia. Sans immunoreactivity is especially robust in the region beneath the basal body of the kinocilium in $\mathrm{OHCs}$ 
(Adato et al., 2005b) and Sans is also found in the kinocilium (Adato et al., 2005b). Based on its localization beneath the cuticular plate where vesicles and microtubules are concentrated, it has been suggested that Sans may function to traffic proteins along microtubules and actin filaments toward the stereocilia and kinocilium (Reiners et al., 2006; El-Amraoui and Petit 2005; Adato et al., 2005b). In the Jackson shaker mouse, mutations in Sans cause defects in hair-bundle development (Kikkawa et al., 2003).

\section{Actin cross linkers}

Two actin cross linking proteins are expressed in the actin cores of developing and mature stereocilia, espin and I-plastin (fimbrin) (Zine and Romand, 1996, Zheng et al., 2000; Li et al., 2004) and a third, T-plastin, is expressed only transiently as the hair bundle develops (Daudet and Lebart, 2002). There are four isoforms of espin expressed in the inner ear, all of which have a C-terminal actin bundling domain and a Wiskott-Aldrich Syndrome protein homology $2(\mathrm{WH} 2)$ domain and they show complex variations in their temporal expression patterns during cochlear development (Sekerkova et al., 2006) with the longest isoform (espin1 with 8 ankyrin repeats) and the shortest (espin 4 with PIP2 binding activity) becoming predominant during the later stages of hair-bundle maturation. Espin can be detected in hair bundles shortly after they have first emerged ( $\mathrm{Li}$ et al., 2004) and espin levels in mature hair bundles correlate with hair-bundle length (Loomis et al., 2003). Levels of espin expression have been experimentally shown to regulate the length of microvilli in cultured epithelial cells (Loomis et al., 2003) and the overexpression of espin in cochlear hair cells causes a lengthening of the hair bundle (Rzadzinska et al., 2005). The over-expression of espin in cochlear supporting cells can lead to the appearance of structures that resemble hair bundles. These studies all suggest a critical role for espin in hair-bundle development, and hair bundle defects have been described in the cochlea of the espin-deficient jerker mouse (Zheng etal., 2000) by P12 (Sjöström and Anniko, 1992). There may however be some degree of functional redundancy amongst the actin-bundling proteins. The consequences of deleting one or more plastin-family members on hair-bundle development are, as yet, unknown.

\section{Other proteins likely to be required for hair-bundle devel- opment}

The study of genes required for hearing in man has revealed a number of interesting proteins that may well prove, on the basis of their localisation or known functions, to be involved in various aspects of the development and maintenance of hairbundle structure. These include the F-actin and TRIO-binding protein, TRIOBP, mutations in which cause prelingual hearing loss at the nonsyndromic hearing loss locus DFNB28 (Riazuddin et al., 2006; Shahin et al., 2006), the human orthologue of diaphanous, HDIA, a downstream target of RhoA that when mutated causes progressive hearing loss at the DFNA1 locus (Lynch et al., 1997) and myosin Illa, an unconventional myosin that locates to the distal ends of stereocilia (Schneider et al., 2006) and is mutated in the progressive, late-onset recessive form of deafness DFNB30 (Walsh et al., 2002). DOCK4, a guanine nucleotide exchange factor (GEF) for Rho GTPase and a potent Rac activator (Yan et al., 2006) that was identified on the basis of its interactions with harmonin in a yeast 2-hybrid screen may be required for hair-bundle development, as may vezatin, a transmembrane protein of the adherens junction that interacts with myosin VIla and locates to the ankle region of the hair bundle (Kussl-Andermann et al., 2000). Other proteins required for the development or maintenance of hair bundles include radixin (Kitajiri et al., 2004), chloride intracellular channel 5 (Clic5, Gagnon et al., 2006), a transmembrane protein expressed in the inner ear (Tmie, Mitchem et al., 2002) and a tetraspan membrane protein expressed in hair cell stereocilia (Tmhs, Longo-Guess et al., 2005).

\section{Control of hair-bundle form}

Hair bundles of the inner ear come in a huge variety of shapes and sizes. In the cristae of the semi-circular canals they are of a roughly conical shape and extremely tall, with stereocilia that can be 40 microns or more in length, whilst in the cochlea they have a $\mathrm{W}$ - or $\mathrm{V}$-shape and can have very short stereocilia (1 micron high in the basal coils of some species). Even within one organ there can be considerable variation in hair-bundle morphology. The pathways that may control hairbundle form are far from being resolved, although recent evidence suggests a role for the Wnt signalling pathway. Forced expression of activated $\beta$-catenin within the avian basilar papilla results in the formation of patches of hair cells with a distinctly vestibular phenotype (Stevens et al., 2003). Preliminary evidence also indicates that hedgehog signalling may control specification of hair-cell type in the mammalian cochlea. In mice that only express the truncated repressor form of Gli3, a transcription factor than can act as both an activator and a repressor of hedgehog signalling, hair cells in the cochlea acquire a vestibular phenotype with conical-shaped hair bundles as opposed to the characteristic V-or W-shape of auditory hair bundles (Driver et al., ARO abstract, 2006).

\section{Conclusion}

Rapid progress has been made in our understanding of the molecular mechanisms underlying the process of hair-bundle development, due in large part to the study of mouse and zebrafish mutants and the discovery of genes required for hearing, many of which encode proteins required for the development and maintenance of hair-bundle structure. Nonetheless, there is still much to be learned and many a puzzle to solve. Notably few, if any, genes have been identified that affect the very earliest stages of hair-bundle development and the initiation of stereociliary ranking. In most mutants that have been described to date, the hair bundle forms and has heightranked rows of stereocilia even though the overall shape, form and organisation of the hair bundle is disrupted. It is possible that the genes controlling the very early stages of hair-bundle development are also essential for basic fundamental processes and required for normal development of the embryo. Mutations in these genes may be lethal. Dissecting the interaction pathways and determining which of the potential proteinprotein interactions revealed by in vitro pull down assays are relevant for normal development will be one important task for 
the future, as will determining the pathways that control the final form, shape, and physiological properties of each hair bundle, both in the different sensory organs and along the length of the cochlea.

\section{References}

ADATO, A., LEFEVRE, G., DELPRAT, B., MICHEL, V., MICHALSKI, N., CHARDENOUX, S., WEIL, D., EL-AMRAOUI, A. and PETIT, C. (2005a). Usherin, the defective protein in Usher syndrome type IIA, is likely to be a component of interstereocilia ankle links in the inner ear sensory cells. Hum Mo/ Genet 14: 3921-32

ADATO, A., MICHEL, V., KIKKAWA, Y., REINERS, J., ALAGRAMAM, K.N., WEIL, D., YONEKAWA, H., WOLFRUM, U., EL-AMRAOUI, A. and PETIT, C. (2005b). Interactions in the network of Usher syndrome type 1 proteins. Hum Mol Genet 14: 347-56.

AHMED, Z.M., GOODYEAR, R., RIAZUDDIN, S., LAGZIEL, A., LEGAN, P.K., BEHRA, M., BURGESS, S.M., LILLEY, K.S., WILCOX, E.R., GRIFFITH, A.J. et al., (2006). The tip-link antigen, a protein associated with the transduction complex of sensory hair cells, is protocadherin-15. J Neurosci26: 7022-34.

AHMED, Z.M., RIAZUDDIN, S., BERNSTEIN, S.L., AHMED, Z., KHAN, S., GRIFFITH, A.J., MORELL, R.J., FRIEDMAN, T.B. and WILCOX, E.R. (2001). Mutations of the protocadherin gene PCDH15 cause Usher syndrome type $1 \mathrm{~F}$. Am J Hum Genet 69: 25-34.

ALAGRAMAM, K.N., MURCIA, C.L., KWON, H.Y., PAWLOWSKI, K.S., WRIGHT, C.G. and WOYCHIK, R.P. (2001). The mouse Ames waltzer hearing-loss mutant is caused by mutation of Pcdh 15 , a novel protocadherin gene. Nat Genet 27: $99-102$

ANDERSON, D.W., PROBST, F.J., BELYANTSEVA, I.A., FRIDELL, R.A., BEYER, L., MARTIN, D.M., WU, D., KACHAR, B., FRIEDMAN, T.B., RAPHAEL, Y. et al. (2000). The motor and tail regions of myosin $\mathrm{XV}$ are critical for normal structure and function of auditory and vestibular hair cells. Hum Mol Genet 9: 1729-38.

ASSAD, J.A., SHEPHERD, G.M. and COREY, D.P. (1991). Tip-link integrity and mechanical transduction in vertebrate hair cells. Neuron 7: 985-94.

AVRAHAM, K.B., HASSON, T., STEEL, K.P., KINGSLEY, D.M., RUSSELL, L.B., MOOSEKER, M.S., COPELAND, N.G. and JENKINS, N.A. (1995). The mouse Snell's waltzer deafness gene encodes an unconventional myosin required for structural integrity of inner ear hair cells. Nat Genet 11: 369-75.

BAGGER-SJOBACK, D. and WERSALL, J. (1973). The sensory hairs and tectorial membrane of the basilar papilla in the lizard Calotes versicolor. J Neurocyto/2: 329-50.

BARTOLAMI, S., GOODYEAR, R. and RICHARDSON, G. (1991). Appearance and distribution of the $275 \mathrm{kD}$ hair-cell antigen during development of the avian inner ear. J Comp Neuro/314: 777-88.

BELYANTSEVA, I.A., BOGER, E.T. and FRIEDMAN, T.B. (2003). Myosin XVa localizes to the tips of inner ear sensory cell stereocilia and is essential for staircase formation of the hair bundle. Proc Nat/ Acad Sci USA 100: 13958-63.

BELYANTSEVA, I.A., BOGER, E.T., NAZ, S., FROLENKOV, G.I., SELLERS, J.R., AHMED, Z.M., GRIFFITH, A.J. and FRIEDMAN, T.B. (2005). Myosin-XVa is required for tip localization of whirlin and differential elongation of hair-cell stereocilia. Nat Cel/ Bio/7: 148-56.

BEYER, L.A., ODEH, H., PROBST, F.J., LAMBERT, E.H., DOLAN, D.F., CAMPER, S.A., KOHRMAN, D.C. and RAPHAEL, Y. (2000). Hair cells in the inner ear of the pirouette and shaker 2 mutant mice. J Neurocyto/29: 227-40.

BOËDA, B., EL-AMRAOUI, A., BAHLOUL, A., GOODYEAR, R., DAVIET, L., BLANCHARD, S., PERFETTINI, I., FATH, K.R., SHORTE, S., REINERS, J. et al. (2002). Myosin VIla, harmonin and cadherin 23, three Usher I gene products that cooperate to shape the sensory hair cell bundle. EMBO J21: 6689-99.

BORK, J.M., PETERS, L.M., RIAZUDDIN, S., BERNSTEIN, S.L., AHMED, Z.M., NESS, S.L., POLOMENO, R., RAMESH, A., SCHLOSS, M., SRISAILPATHY, C.R. et al. (2001). Usher syndrome 1D and nonsyndromic autosomal recessive deafness DFNB12 are caused by allelic mutations of the novel cadherin-like gene CDH23. Am J Hum Genet 68: 26-37.

BUSS, F., ARDEN, S.D., LINDSAY, M., LUZIO, J.P. and KENDRICK-JONES, J. (2001). Myosin VI isoform localized to clathrin-coated vesicles with a role in clathrin-mediated endocytosis. EMBO J20: 3676-84.
CRAMER, L.P. (2000). Myosin VI: roles for a minus end-directed actin motor in cells. J Cell Biol 150: F121-6.

CSUKAS, S.R., ROSENQUIST, T.H. and MULROY, M.J. (1987). Connections between stereocilia in auditory hair cells of the alligator lizard. HearRes 30: 14755.

DAUDET, N. and LEBART, M.C. (2002). Transient expression of the t-isoform of plastins/fimbrin in the stereocilia of developing auditory hair cells. Cell Motil Cytoskeleton 53: 326-36.

DELPRAT, B., MICHEL, V., GOODYEAR, R., YAMASAKI, Y., MICHALSKI, N., ELAMRAOUI, A., PERFETTINI, I., LEGRAIN, P., RICHARDSON, G., HARDELIN, J.P. et al. (2005). Myosin XVa and whirlin, two deafness gene products required for hair bundle growth, are located at the stereocilia tips and interact directly. Hum Mol Genet 14: 401-10.

DEMONTIS, F., HABERMANN, B. and DAHMANN, C. (2006). PDZ-domainbinding sites are common among cadherins. Dev Genes Evo/216: 737-41.

DENMAN-JOHNSON, K. and FORGE, A. (1999). Establishment of hair bundle polarity and orientation in the developing vestibular system of the mouse. $J$ Neurocyto/28: 821-35.

DI PALMA, F., HOLME, R.H., BRYDA, E.C., BELYANTSEVA, I.A., PELLEGRINO, R., KACHAR, B., STEEL, K.P. and NOBEN-TRAUTH, K. (2001a). Mutations in Cdh23, encoding a new type of cadherin, cause stereocilia disorganization in waltzer, the mouse model for Usher syndrome type 1D. Nat Genet 27: 103-7.

DI PALMA, F., PELLEGRINO, R. and NOBEN-TRAUTH, K. (2001b). Genomic structure, alternative splice forms and normal and mutant alleles of cadherin 23 (Cdh23). Gene 281: 31-41.

DRIVER, E., PRYOR, S., HILL, P., TURNER, J., RÂŸTHER, U., BIESECKER, L., GRIFFITH, A.J. and KELLEY, M.W. (2006). Hedgehog Signaling and GLI3 Are Required for Development of the Mammalian Cochlear Sensory Epithelium. Assoc. Res. Otolaryngo/Abstract 277.

EL-AMRAOUI, A. and PETIT, C. (2005). Usher I syndrome: unravelling the mechanisms that underlie the cohesion of the growing hair bundle in inner ear sensory cells. J Cell Sci118: 4593-603.

ERNEST, S., RAUCH, G.J., HAFFTER, P., GEISLER, R., PETIT, C. and NICOLSON, T. (2000). Mariner is defective in myosin VIIA: a zebrafish model for human hereditary deafness. Hum Mol Genet 9: 2189-96.

ERNSTSON, S. and SMITH, C.A. (1986). Stereo-kinociliar bonds in mammalian vestibular organs. Acta Otolaryngo/101: 395-402.

EUDY, J.D., WESTON, M.D., YAO, S., HOOVER, D.M., REHM, H.L., MA-EDMONDS, M., YAN, D., AHMAD, I., CHENG, J.J., AYUSO, C. et al. (1998). Mutation of a gene encoding a protein with extracellular matrix motifs in Usher syndrome type Ila. Science 280: 1753-7.

FETTIPLACE, R. (2006). Active hair bundle movements in auditory hair cells. $J$ Physio/576: 29-36.

FURNESS, D.N. and HACKNEY, C.M. (1985). Cross-links between stereocilia in the guinea pig cochlea. Hear Res 18: 177-88.

FURNESS, D.N., RICHARDSON, G.P. and RUSSELL, I.J. (1989). Stereociliary bundle morphology in organotypic cultures of the mouse cochlea. HearRes 38 : 95-109.

GAGNON, L. H., LONGO-GUESS, C. M., BERRYMAN, M., SHIN, J. B., SAYLOR, K. W., YU, H., GILLESPIE, P., G. JOHNSON, K. R. (2006). The chloride intracellular channel protein CLIC5 is expressed at high levels in hair cell stereocilia and is essential for normal inner ear function. JNeurosci26: 1018898.

GALE, J.E., MARCOTTI, W., KENNEDY, H.J., KROS, C.J. and RICHARDSON, G.P. (2001). FM1-43 dye behaves as a permeant blocker of the hair-cell mechanotransducer channel. J Neurosci21: 7013-25.

GELEOC, G.S. and HOLT, J.R. (2003). Developmental acquisition of sensory transduction in hair cells of the mouse inner ear. Nat Neurosci 6: 1019-20.

GIBSON, F., WALSH, J., MBURU, P., VARELA, A., BROWN, K.A., ANTONIO, M., BEISEL, K.W., STEEL, K.P. and BROWN, S.D. (1995). A type VII myosin encoded by the mouse deafness gene shaker-1. Nature 374: 62-4.

GOODWIN, M. and YAP, A.S. (2004). Classical cadherin adhesion molecules: coordinating cell adhesion, signaling and the cytoskeleton. JMol Histo/35: 83944.

GOODYEAR, R. and RICHARDSON, G. (1992). Distribution of the $275 \mathrm{kD}$ hair cell antigen and cell surface specialisations on auditory and vestibular hair bundles 
in the chicken inner ear. J Comp Neuro/325: 243-56.

GOODYEAR, R. and RICHARDSON, G. (1999). The ankle-link antigen: an epitope sensitive to calcium chelation associated with the hair-cell surface and the calycal processes of photoreceptors. J Neurosci 19: 3761-72.

GOODYEAR, R.J., LEGAN, P.K., WRIGHT, M.B., MARCOTTI, W., OGANESIAN, A., COATS, S.A., BOOTH, C.J., KROS, C.J., SEIFERT, R.A., BOWEN-POPE, D.F. et al. (2003). A receptor-like inositol lipid phosphatase is required for the maturation of developing cochlear hair bundles. J Neurosci23: 9208-19.

GOODYEAR, R.J., MARCOTTI, W., KROS, C.J. and RICHARDSON, G.P. (2005). Development and properties of stereociliary link types in hair cells of the mouse cochlea. J Comp Neuro/485: 75-85.

GOODYEAR, R.J. and RICHARDSON, G.P. (2003). A novel antigen sensitive to calcium chelation that is associated with the tip links and kinocilial links of sensory hair bundles. J Neurosci23: 4878-87.

HASSON, T., GILLESPIE, P.G., GARCIA, J.A., MACDONALD, R.B., ZHAO, Y., YEE, A.G., MOOSEKER, M.S. and COREY, D.P. (1997). Unconventional myosins in inner-ear sensory epithelia. J Cell Bio/137: 1287-307.

HENN, A. and DE LA CRUZ, E.M. (2005). Vertebrate myosin VIlb is a high duty ratio motor adapted for generating and maintaining tension. J Biol Chem280: 3966576.

HILLMAN, D.E. (1969). New ultrastructural findings regarding a vestibular ciliary apparatus and its possible functional significance. Brain Res 13: 407-12.

HOLME, R. H., and K. P. STEEL (2002). Stereocilia defects in waltzer (Cdh23), shaker1 (Myo7a) and double waltzer/shaker1 mutant mice. Hear Res 169: 1323.

HOLME, R.H., KIERNAN, B.W., BROWN, S.D. and STEEL, K.P. (2002). Elongation of hair cell stereocilia is defective in the mouse mutant whirler. $J$ Comp Neurol 450: 94-102.

IMAMURA, Y., ITOH, M., MAENO, Y., TSUKITA, S. and NAGAFUCHI, A. (1999). Functional domains of alpha-catenin required for the strong state of cadherinbased cell adhesion. J Cel/ Bio/144: 1311-22.

JACOBS, R.A. and HUDSPETH, A.J. (1990). Ultrastructural correlates of mechanoelectrical transduction in hair cells of the bullfrog's internal ear. Cold Spring Harb Symp Quant Bio/55: 547-61.

JOHNSON, K.R., GAGNON, L.H., WEBB, L.S., PETERS, L.L., HAWES, N.L., CHANG, B. and ZHENG, Q.Y. (2003). Mouse models of USH1C and DFNB18: phenotypic and molecular analyses of two new spontaneous mutations of the Ush1c gene. Hum Mol Genet 12: 3075-86.

JOHNSON, K.R., ZHENG, Q.Y., WESTON, M.D., PTACEK, L.J. and NOBENTRAUTH, K. (2005). The Mass 1 frings mutation underlies early onset hearing impairment in BUB/BnJ mice, a model for the auditory pathology of Usher syndrome IIC. Genomics 85: 582-90.

KACHAR, B., PARAKKAL, M., KURC, M., ZHAO, Y. and GILLESPIE, P.G. (2000). High-resolution structure of hair-cell tip links. Proc Natl Acad Sci U S A 97: 13336-41.

KALTENBACH, J.A., FALZARANO, P.R. and SIMPSON, T.H. (1994). Postnatal development of the hamster cochlea. II. Growth and differentiation of stereocilia bundles. J Comp Neuro/350: 187-98.

KAROLYI, I. J., PROBST, F. J., BEYER, L., ODEH, H., DOOTZ, G., CHA, K. B., MARTIN, D. M., AVRAHAM, K. B., KOHRMAN, D., DOLAN, D. F., RAPHAEL, Y., CAMPER, S. A. (2003). Myo15 function is distinct from Myo6, Myo7a and pirouette genes in development of cochlear stereocilia. Hum Mol Genet 12: 2797-805.

KIKKAWA, Y., MBURU, P., MORSE, S., KOMINAMI, R., TOWNSEND, S. and BROWN, S.D. (2005). Mutant analysis reveals whirlin as a dynamic organizer in the growing hair cell stereocilium. Hum Mol Genet 14: 391-400.

KIKKAWA, Y., SHITARA, H., WAKANA, S., KOHARA, Y., TAKADA, T., OKAMOTO, M., TAYA, C., KAMIYA, K., YOSHIKAWA, Y., TOKANO, H. et al. (2003). Mutations in a new scaffold protein Sans cause deafness in Jackson shaker mice. Hum Mol Genet 12: 453-61.

KITAJIRI, S., FUKUMOTO, K., HATA, M., SASAKI, H., KATSUNO, T., NAKAGAWA, T., ITO, J., TSUKITA, S. (2004). Radixin deficiency causes deafness associated with progressive degeneration of cochlear stereocilia. J Cell Bio/166: 559-70.

KREMER, H., VAN WIJK, E., MARKER, T., WOLFRUM, U. and ROEPMAN, R. (2006). Usher syndrome: molecular links of pathogenesis, proteins and pathways. Hum Mol Genet 15 Spec No 2: R262-70.
KUSSEL-ANDERMANN, P., EL-AMRAOUI, A., SAFIEDDINE, S., NOUAILLE, S., PERFETTINI, I., LECUIT, M., COSSART, P., WOLFRUM, U. and PETIT, C. (2000). Vezatin, a novel transmembrane protein, bridges myosin VIIA to the cadherin-catenins complex. EMBO J19: 6020-9.

LAGZIEL, A., AHMED, Z.M., SCHULTZ, J.M., MORELL, R.J., BELYANTSEVA, I.A. and FRIEDMAN, T.B. (2005). Spatiotemporal pattern and isoforms of cadherin 23 in wild type and waltzer mice during inner ear hair cell development. Dev Biol 280: 295-306.

LI, H., LIU, H., BALT, S., MANN, S., CORRALES, C.E. and HELLER, S. (2004). Correlation of expression of the actin filament-bundling protein espin with stereociliary bundle formation in the developing inner ear. J Comp Neuro/468: 125-34.

LIU, X., BULGAKOV, O.V., DARROW, K.N., PAWLYK, B., ADAMIAN, M., LIBERMAN, M.C. and LI, T. (2007). Usherin is required for maintenance of retinal photoreceptors and normal development of cochlear hair cells. ProcNat/ Acad Sci USA 104: 4413-8.

LONGO-GUESS, C. M., GAGNON, L. H., COOK, S. A., WU, J., ZHENG, Q. Y., JOHNSON, K. R. (2005). A missense mutation in the previously undescribed gene Tmhs underlies deafness in hurry-scurry (hscy) mice. Proc Nat/ Acad Sci US A 102: 7894-9.

LOOMIS, P.A., ZHENG, L., SEKERKOVA, G., CHANGYALEKET, B., MUGNAINI, E. and BARTLES, J.R. (2003). Espin cross-links cause the elongation of microvillus-type parallel actin bundles in vivo. J Cel/ Bio/163: 1045-55.

LYNCH, E.D., LEE, M.K., MORROW, J.E., WELCSH, P.L., LEON, P.E. and KING, M.C. (1997). Nonsyndromic deafness DFNA1 associated with mutation of a human homolog of the Drosophila gene diaphanous. Science 278: 1315-8.

MBIENE, J.P. and SANS, A. (1986). Differentiation and maturation of the sensory hair bundles in the fetal and postnatal vestibular receptors of the mouse: a scanning electron microscopy study. J Comp Neuro/254: 271-8.

MBURU, P., KIKKAWA, Y., TOWNSEND, S., ROMERO, R., YONEKAWA, H. and BROWN, S.D. (2006). Whirlin complexes with p55 at the stereocilia tip during hair cell development. Proc Natl Acad Sci USA 103: 10973-8.

MBURU, P., MUSTAPHA, M., VARELA, A., WEIL, D., EL-AMRAOUI, A., HOLME, R.H., RUMP, A., HARDISTY, R.E., BLANCHARD, S., COIMBRA, R.S. et al. (2003). Defects in whirlin, a PDZ domain molecule involved in stereocilia elongation, cause deafness in the whirler mouse and families with DFNB31. Nat Genet 34: 421-8.

MCGEE, J., GOODYEAR, R.J., MCMILLAN, D.R., STAUFFER, E.A., HOLT, J.R., LOCKE, K.G., BIRCH, D.G., LEGAN, P.K., WHITE, P.C., WALSH, E.J. et al. (2006). The very large G-protein-coupled receptor VLGR1: a component of the ankle link complex required for the normal development of auditory hair bundles. J Neurosci 26: 6543-53.

McMILLAN, D. R., KAYES-WANDOVER, K. M., RICHARDSON, J. A., WHITE, P. C. (2002). Very large G protein-coupled receptor-1, the largest known cell surface protein, is highly expressed in the developing central nervous system. $J$ Biol Chem 277: 785-92.

MICHEL, V., GOODYEAR, R.J., WEIL, D., MARCOTTI, W., PERFETTINI, I., WOLFRUM, U., KROS, C.J., RICHARDSON, G.P. and PETIT, C. (2005). Cadherin 23 is a component of the transient lateral links in the developing hair bundles of cochlear sensory cells. Dev Bio/280: 281-94.

MITCHEM, K. L., HIBBARD, E., BEYER, L. A., BOSOM, K., DOOTZ, G. A., DOLAN, D. F., JOHNSON, K. R., RAPHAEL, Y., KOHRMAN, D. C. (2002). Mutation of the novel gene Tmie results in sensory cell defects in the inner ear of spinner, a mouse model of human hearing loss DFNB6. Hum Mol Genet 11: 1887-98.

MOOSEKER, M.S. and CHENEY, R.E. (1995). Unconventional myosins. Annu Rev Cell Dev Bio/11: 633-75.

NAGEL, G., NEUGEBAUER, D.C., SCHMIDT, B. and THURN, U. (1991). Structures transmitting stimulatory force to the sensory hairs of vestibular ampullae of fishes and frogs. Cell Tissue Res 265: 567-578.

NEUGEBAUER, D.C. and THURN, U. (1985). Interconnections between the stereovilli of the fish inner ear. Cell Tissue Res 240: 449-453.

NICOLSON, T., RUSCH, A., FRIEDRICH, R.W., GRANATO, M., RUPPERSBERG, J.P. and NUSSLEIN-VOLHARD, C. (1998). Genetic analysis of vertebrate sensory hair cell mechanosensation: the zebrafish circler mutants. Neuron 20: 271-83.

NOURRY, C., GRANT, S.G. and BORG, J.P. (2003). PDZ domain proteins: plug and play! SCI STKE2003: RE7. 
OGANESIAN, A., POOT, M., DAUM, G., COATS, S.A., WRIGHT, M.B., SEIFERT, R.A. and BOWEN-POPE, D.F. (2003). Protein tyrosine phosphatase RQ is a phosphatidylinositol phosphatase that can regulate cell survival and proliferation. Proc Natl Acad Sci USA 100: 7563-8.

PICKLES, J.O., COMIS, S.D. and OSBORNE, M.P. (1984). Cross-links between stereocilia in the guinea pig organ of Corti and their possible relation to sensory transduction. Hear Res 15: 103-12.

PICKLES, J.O., VON PERGER, M., ROUSE, G.W. and BRIX, J. (1991). The development of links between stereocilia in hair cells of the chick basilar papilla. Hear Res 54: 153-63.

PRIETO, J.J. and MERCHAN, J.A. (1986). Tannic acid staining of the cell coat of the organ of Corti. Hear Res 24: 237-41.

REINERS, J., NAGEL-WOLFRUM, K., JURGENS, K., MARKER, T. and WOLFRUM, $U$. (2006). Molecular basis of human Usher syndrome: deciphering the meshes of the Usher protein network provides insights into the pathomechanisms of the Usher disease. Exp Eye Res 83: 97-119.

REINERS, J., VAN WIJK, E., MARKER, T., ZIMMERMANN, U., JURGENS, K., TE BRINKE, H., OVERLACK, N., ROEPMAN, R., KNIPPER, M., KREMER, H. et al. (2005). Scaffold protein harmonin (USH1C) provides molecular links between Usher syndrome type 1 and type 2. Hum Mol Genet 14: 3933-43.

RIAZUDDIN, S., KHAN, S.N., AHMED, Z.M., GHOSH, M., CAUTION, K., NAZLI, S., KABRA, M., ZAFAR, A.U., CHEN, K., NAZ, S. et al. (2006). Mutations in TRIOBP, which encodes a putative cytoskeletal-organizing protein, are associated with nonsyndromic recessive deafness. Am J Hum Genet 78: 137-43.

RICHARDSON, G.P., BARTOLAMI, S. and RUSSELL, I.J. (1990). Identification of a $275-k D$ protein associated with the apical surfaces of sensory hair cells in the avian inner ear. $J$ Cell Biol110: 1055-66

RZADZINSKA, A.K., DERR, A., KACHAR, B. and NOBEN-TRAUTH, K. (2005). Sustained cadherin 23 expression in young and adult cochlea of normal and hearing-impaired mice. Hear Res 208: 114-21.

RZADZINSKA, A.K., SCHNEIDER, M.E., DAVIES, C., RIORDAN, G.P. and KACHAR, B. (2004). An actin molecular treadmill and myosins maintain stereocilia functional architecture and self-renewal. J Cel/ Bio/164: 887-97.

SANTI, P.A. and ANDERSON, C.B. (1987). A newly identified surface coat on cochlear hair cells. Hear Res 27: 47-65.

SCHNEIDER, M.E., BELYANTSEVA, I.A., AZEVEDO, R.B. and KACHAR, B. (2002). Rapid renewal of auditory hair bundles. Nature 418: 837-8.

SCHNEIDER, M. E., DOSE, A. C., SALLES, F. T., CHANG, W., ERICKSON, F. L., BURNSIDE, B., KACHAR, B. (2006). A new compartment at stereocilia tips defined by spatial and temporal patterns of myosin Illa expression. J NeurosCl 26: 10243-52.

SEDGWICK, S.G. and SMERDON, S.J. (1999). The ankyrin repeat: a diversity of interactions on a common structural framework. Trends Biochem Sci24: 311 6.

SEIFERT, R.A., COATS, S.A., OGANESIAN, A., WRIGHT, M.B., DISHMON, M., BOOTH, C.J., JOHNSON, R.J., ALPERS, C.E. and BOWEN-POPE, D.F. (2003). PTPRQ is a novel phosphatidylinositol phosphatase that can be expressed as a cytoplasmic protein or as a subcellularly localized receptor-like protein. Exp Cell Res 287: 374-86.

SEILER, C., BEN-DAVID, O., SIDI, S., HENDRICH, O., RUSCH, A., BURNSIDE, B., AVRAHAM, K.B. and NICOLSON, T. (2004). Myosin VI is required for structural integrity of the apical surface of sensory hair cells in zebrafish. Dev Bio/272: 328-38

SEILER, C., FINGER-BAIER, K.C., RINNER, O., MAKHANKOV, Y.V., SCHWARZ, H., NEUHAUSS, S.C. and NICOLSON, T. (2005). Duplicated genes with split functions: independent roles of protocadherin 15 orthologues in zebrafish hearing and vision. Development 132: 615-23.

SEKERKOVA, G., ZHENG, L., MUGNAINI, E. and BARTLES, J.R. (2006). Differential expression of espin isoforms during epithelial morphogenesis, stereociliogenesis and postnatal maturation in the developing inner ear. Dev Biol291: 83-95.

SELF, T., MAHONY, M., FLEMING, J., WALSH, J., BROWN, S.D. and STEEL, K.P. (1998). Shaker-1 mutations reveal roles for myosin VIIA in both development and function of cochlear hair cells. Development 125: 557-66.

SELF, T., SOBE, T., COPELAND, N.G., JENKINS, N.A., AVRAHAM, K.B. and STEEL, K.P. (1999). Role of myosin VI in the differentiation of cochlear hair cells. Dev Bio/214: 331-41.

SHAHIN, H., WALSH, T., SOBE, T., ABU SA'ED, J., ABU RAYAN, A., LYNCH, E.D., LEE, M.K., AVRAHAM, K.B., KING, M.C. and KANAAN, M. (2006). Mutations in a novel isoform of TRIOBP that encodes a filamentous-actin binding protein are responsible for DFNB28 recessive nonsyndromic hearing loss. Am J Hum Genet 78: 144-52.

SI, F., BRODIE, H., GILLESPIE, P.G., VAZQUEZ, A.E. and YAMOAH, E.N. (2003). Developmental assembly of transduction apparatus in chick basilar papilla. $J$ Neurosci23: 10815-26.

SIEMENS, J., KAZMIERCZAK, P., REYNOLDS, A., STICKER, M., LITTLEWOODEVANS, A. and MULLER, U. (2002). The Usher syndrome proteins cadherin 23 and harmonin form a complex by means of PDZ-domain interactions. Proc Nat/ Acad Sci USA 99: 14946-51.

SIEMENS, J., LILLO, C., DUMONT, R.A., REYNOLDS, A., WILLIAMS, D.S., GILLESPIE, P.G. and MÜLLER, U. (2004). Cadherin 23 is a component of the tip link in hair-cell stereocilia. Nature 428: 950-5.

SJÖSTRÖM, B., ANNIKO, M. (1992). Genetically induced inner ear degeneration. A structural and functional study. Acta Otolaryngo/Suppl 493: 141-6.

SLEPECKY, N. and CHAMBERLAIN, S.C. (1985). Immunoelectron microscopic and immunofluorescent localization of cytoskeletal and muscle-like contractile proteins in inner ear sensory hair cells. Hear Res 20: 245-60.

SOLLNER, C., RAUCH, G.J., SIEMENS, J., GEISLER, R., SCHUSTER, S.C., MÜLLER, U. and NICOLSON, T. (2004). Mutations in cadherin 23 affect tip links in zebrafish sensory hair cells. Nature 428: 955-9.

SOUTER, M., NEVILL, G. and FORGE, A. (1995). Postnatal development of membrane specialisations of gerbil outer hair cells. Hear Res 91: 43-62.

STEVENS, C.B., DAVIES, A.L., BATTISTA, S., LEWIS, J.H. and FEKETE, D.M. (2003). Forced activation of Wnt signaling alters morphogenesis and sensory organ identity in the chicken inner ear. Dev Bio/261: 149-64.

TAKENAWA, T. and ITOH, T. (2001). Phosphoinositides, key molecules for regulation of actin cytoskeletal organization and membrane traffic from the plasma membrane. Biochim Biophys Acta 1533: 190-206.

TEPASS, U., TRUONG, K., GODT, D., IKURA, M. and PEIFER, M. (2000). Cadherins in embryonic and neural morphogenesis. Nat RevMo/Cel/ Biol1: 91100.

TILNEY, L.G., COTANCHE, D.A. and TILNEY, M.S. (1992). Actin filaments, stereocilia and hair cells of the bird cochlea. VI. How the number and arrangement of stereocilia are determined. Development 116: 213-26.

TSUPRUN, V., GOODYEAR, R.J. and RICHARDSON, G.P. (2004). The structure of tip links and kinocilial links in avian sensory hair bundles. Biophys J87: 410612.

TSUPRUN, V. and SANTI, P. (1998). Structure of outer hair cell stereocilia links in the chinchilla. J Neurocyto/27: 517-28.

TSUPRUN, V. and SANTI, P. (2002). Structure of outer hair cell stereocilia side and attachment links in the chinchilla cochlea. J Histochem Cytochem 50: 493-502.

TSUPRUN, V., SCHACHERN, P.A., CUREOGLU, S. and PAPARELLA, M. (2003). Structure of the stereocilia side links and morphology of auditory hair bundle in relation to noise exposure in the chinchilla. JNeurocyto/32: 1117-28.

VAN WIJK, E., PENNINGS, R.J., TE BRINKE, H., CLAASSEN, A., YNTEMA, H.G., HOEFSLOOT, L.H., CREMERS, F.P., CREMERS, C.W. and KREMER, H. (2004). Identification of 51 novel exons of the Usher syndrome type 2A (USH2A) gene that encode multiple conserved functional domains and that are mutated in patients with Usher syndrome type II. Am J Hum Genet 74: 738-44.

VAN WIJK, E., VAN DER ZWAAG, B., PETERS, T., ZIMMERMANN, U., TE BRINKE, H., KERSTEN, F.F., MARKER, T., ALLER, E., HOEFSLOOT, L.H., CREMERS, C.W. et al. (2006). The DFNB31 gene product whirlin connects to the Usher protein network in the cochlea and retina by direct association with USH2A and VLGR1. Hum Mol Genet 15: 751-65.

VERPY, E., LEIBOVICI, M., ZWAENEPOEL, I., LIU, X.Z., GAL, A., SALEM, N., MANSOUR, A., BLANCHARD, S., KOBAYASHI, I., KEATS, B.J. et al. (2000). A defect in harmonin, a PDZ domain-containing protein expressed in the inner ear sensory hair cells, underlies Usher syndrome type 1C. Nat Genet 26: 51-5.

WALSH, T., WALSH, V., VREUGDE, S., HERTZANO, R., SHAHIN, H., HAIKA, S., LEE, M. K., KANAAN, M., KING, M. C., AVRAHAM, K. B. (2002). From flies' eyes to our ears: mutations in a human class III myosin cause progressive nonsyndromic hearing loss DFNB30. Proc Natl Acad Sci U S A 99. 7518-23. 


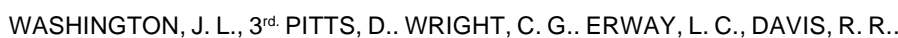
ALAGRAMAM, K. (2005). Characterization of a new allele of Ames waltzer generated by ENU mutagenesis. Hear Res 202: 161-9.

WEIL, D., EL-AMRAOUI, A., MASMOUDI, S., MUSTAPHA, M., KIKKAWA, Y., LAINE, S., DELMAGHANI, S., ADATO, A., NADIFI, S., ZINA, Z.B. et al. (2003). Usher syndrome type IG (USH1G) is caused by mutations in the gene encoding SANS, a protein that associates with the USH1C protein, harmonin. Hum Mol Genet 12: 463-71.

WELLS, A.L., LIN, A.W., CHEN, L.Q., SAFER, D., CAIN, S.M., HASSON, T., CARRAGHER, B.O., MILLIGAN, R.A. and SWEENEY, H.L. (1999). Myosin VI is an actin-based motor that moves backwards. Nature 401: 505-8.

WILSON, S.M., HOUSEHOLDER, D.B., COPPOLA, V., TESSAROLLO, L., FRITZSCH, B., LEE, E.C., GOSS, D., CARLSON, G.A., COPELAND, N.G. and JENKINS, N.A. (2001). Mutations in Cdh23 cause nonsyndromic hearing loss in waltzer mice. Genomics 74: 228-33.

YAGI, H., TOKANO, H., MAEDA, M., TAKABAYASHI, T., NAGANO, T., KIYAMA, H., FUJIEDA, S., KITAMURA, K. and SATO, M. (2007). VIgr1 is required for proper stereocilia maturation of cochlear hair cells. Genes Cells 12: 235-50.

YAN, D., LI, F., HALL, M.L., SAGE, C., HU, W.H., GIALLOURAKIS, C., UPADHYAY, G., OUYANG, X.M., DU, L.L., BETHEA, J.R. etal. (2006). An isoform of GTPase regulator DOCK4 localizes to the stereocilia in the inner ear and binds to harmonin (USH1C). J Mol Bio/357: 755-64.

ZHENG, L., SEKERKOVA, G., VRANICH, K., TILNEY, L.G., MUGNAINI, E. and BARTLES, J.R. (2000). The deaf jerker mouse has a mutation in the gene encoding the espin actin-bundling proteins of hair cell stereocilia and lacks espins. Cel/102: 377-85.

ZIMMERMANN, P. (2006). The prevalence and significance of PDZ domainphosphoinositide interactions. Biochim Biophys Acta 1761: 947-56.

ZINE, A. and ROMAND, R. (1996). Development of the auditory receptors of the rat: a SEM study. Brain Res 721: 49-58.

\section{Related, previously published Int. J. Dev. Biol. articles}

See our Special Issue Ear Development edited by Fernando Giraldez and Bernd Fritzsch at: http://www.ijdb.ehu.es/web/contents.php?vol=51\&issue=6-7

\section{Analysis of Netrin 1 receptors during inner ear development}

Tanja Matilainen, Maarja Haugas, Jordan A. Kreidberg and Marjo Salminen

Int. J. Dev. Biol. (2007) 51: 409-414

Cell proliferation during the early compartmentalization of the Xenopus laevis inner ear Quincy A. Quick and Elba E. Serrano

Int. J. Dev. Biol. (2007) 51: 201-210

Mechanical control of tissue morphogenesis during embryological development Donald E. Ingber

Int. J. Dev. Biol. (2006) 50: 255-266

Functional analysis of FGF3 during zebrafish inner ear development

$\checkmark$ Vendrell, D Gimnopoulos, T Becker, T Schimmang

Int. J. Dev. Biol. (2001) 45: S105-S106 